Original Article

Received/Accepted Dates

12.04.2021/23.05.2021

DOI

10.52096/jsrbs.6.1.7.13.22
Journal of Social Research and Behavioral Sciences

Sosyal Araştırmalar ve Davranış Bilimleri Dergisi

ISSN:2149-178X

Volume: 7 Issue: 13 Year: 2021

\title{
COVID 19 Pandemi Döneminde Çevrimiçi Muhasebe Eğitiminin ZOGA Analizi
}

Dr. Öğretim Üyesi Ahmet ÜNSAL

Kırşehir Ahi Evran Üniversitesi

İIBF, İşletme Bölümü

Muhasebe ve Finansman ABD

ahmetunsal@mail.ru

ORCID:0000-0002-8295-5155

\section{Özet}

Bu çalışmada Covid19'dan kaynaklı olağanüstü pandemi döneminde biçimsel eğitim yöntemlerinden kampüsten eğitimle uzaktan muhasebe eğitiminin ZOGA (SWOT) analizi yapılmıştır. Bu amaçla pandemi döneminde muhasebe ve finans dersi üzerine yapılmış nicel ve nitel araştırma yöntemlerinden oluşan yedi çalışmanın bulguları; Çevrimiçi eğitim altyapısı, ders süreci, sınav süreci ve iletişim süreçlerinde incelenmiştir. Buradan edinilen objektif sonuçlar analiz için ZOGA bileşenleri olan; zorluklar, olanaklar, güç ve acizler şeklinde sınıflandırılarak uzaktan muhasebe eğitiminin ZOGA analizi yapılmıştır. Varılan sonuçlara göre özetle uzaktan muhasebe eğitimi yüzyüze eğitime göre zaman, yer, yol tasarrufu sağlayıp eğitimde esneklik sağlamasına karşın, öğretim sürecinde güdüleme, etkileşimi düşük, aktif öğrenmeyi engelleyici, Sınavlarda etiksel seviyesi düşük, biyolojik olarak Sağlıksız, Fırsat eşitsizliği yarattığı ve asosyal acizlikleri eğitim kalitesine olumsuz etkileri bulunmaktadır.

Anahtar Kelimeler: Muhasebe, "Çevrimiçi Eğitim”, Covid 19, “ZOGA Analizi”

\section{In The Pandemic Period Swot Analysis Of Online Accounting Education}

\begin{abstract}
In this study, SWOT analysis of distance accounting education with off-campus education, which is one of the formal education methods during the extraordinary pandemic caused by Covid19, was made. For this purpose, the findings of seven studies consisting of quantitative and qualitative research methods on
\end{abstract}


accounting and finance course during the pandemic period; The online education infrastructure was examined in the course process, exam process and communication processes. Objective results obtained from here are SWOT components for analysis; SWOT analysis of distance accounting education was made by classifying them as difficulties, possibilities, strengths and incapacities. According to the results, in summary, although distance accounting education saves time, place and way and provides flexibility in education compared to face-to-face education, motivation in the teaching process is low, it prevents active learning, the ethical level is low in exams, it is biologically unhealthy, it creates inequality of opportunity and asocial weaknesses affect the quality of education. has negative effects.

Keywords: Accounting, “Online Education", Covid 19, "SWOT Analysis"

\section{Giriş}

COVID19'dan dolayı ortaya çıkan olağanüstü şartlar nedeniyle başta; sağlık, sosyal, ekonomik ve eğitim konularında birçok olumsuzluklar ve kayıplar yaşanmıştır. COVID-19 salgını, dünya çapında öğrenciler ve öğretmenler üzerinde neredeyse evrensel etkilerle eğitim tarihindeki en büyük düzensizlikleri tetikleyerek asosyalliklere neden oldu. Dünya çapında birçok üniversite, öğretim ortalamasını geleneksel yüzyüze eğitimden çevrimiçi öğrenmeye dönüştürmeye karar vermesi yanında tüm kampüs içi etkinlikler ya iptal edildi ya da bir sonraki duyuruya kadar ertelendi. Bu esnada eğitim kurumları yüzyüze eğitimden uzaktan çevrimiçi eğitime geçti. Çevrimiçi eğitim sürecinde canlı veya kayıtlı dersler, çevrimiçi sınavlar ve kısa sınavlar ve performans ödevler aracıllğıyla öğrencileriyle sanal olarak etkileşim kurmak etkileşimlerle yapılmaya çalışıldı. Bu derslerden muhasebe eğitimi, diğer bazı dersler gibi sadece pasif öğrenmeyi değil aynı zamanda aktif öğrenmeyi gerektirdiğinden özellikli bir durum arz etmektedir.

Uzaktan verilen derslerde bazı dersler pratiği sınıfta veya laboratuvarda yapılması zorunlu aktif öğrenmeye dayalı derslerken, bazıları pasif öğrenmeye dayalı derslerden oluşmaktadır. Muhasebe dersleri de pratiği sınıfta aktif öğrenmeye dayalı ders olup, muhasebe eğitim sürecinde gerek ders yürütücülerinin (Derstarların ${ }^{1}$ ) gerekse öğrencilerin eğitimde uzaktan eğitimden etkilenme biçimleri ve içeriklerinin ortaya konulmasını gerektirmektedir. Pandemi sürecinde yapılan bütün niteliksel ve niceliksel araştırmalarda aktif öğrenim veya pasif öğrenim gerektiren derslere ilişkin

\footnotetext{
${ }^{1}$ Üniversitelerde ders veren akademik unvana sahip eğitmenler veya ders yöneticileri anlamında kullanılmıştır.
} 
niteliksel veya niceliksel bir ayrım yapılmasını da gerektirmektedir. Bunun nedeni sınıfta veya laboratuvarda pratiği olan derslerle uygulaması olmayan dersler aynı nitelikte değildir. Uygulaması olan dersler aktif öğrenmeyi yoğun gerektiren derslerken, pasif öğrenim yöntemleri uygulaması düşük düzeyde olan dersleri içermektedir.

\section{Alıntyayın İncelenmesi ve Zoga Unsurlarının Belirlenmesi}

Eğitim, bir konuda kişiler arasında yapılan bilinçli veya bilinçsiz bilgi alış verişi sürecidir. Bilinçlilik gönüllü veya zorunlu eğitimi beraberinde getirirken, bilinçsiz eğitim gönüllü ve rastlantısal öğrenimleri içermektedir. Etkili ve objektif bir ZOGA (SWOT ${ }^{2}$ ) analizi için eğitim biçimlerinin de işlevine göre sınıflandırılmasını gerektirmektedir. Ulusal alıntyayında eğitim türüne göre; a) Örgün Eğitim, b)Açık Eğitim, c) Dışardan Eğitim, d)Yaygın Eğitim olarak sınıflandırılırken, uluslararası alıntyayında genellikle işlevine göre şu şekilde sınıflandırılmaktadır; a) Biçimsel (formal), b) Serbest biçimsel (non-formal) ve c) Abiçimsel (informal) eğitim biçiminde bölümlenmektedir. Eğitimi türlerine göre sınıflamakla işlevine göre sınıflamak arasında anlamsal kargaşalar bulunduğundan bu çalışmamızda işlevsel eğitim biçimlerine göre yapılan eğitim sınıflandırmasından yararlanılmıştır.

2547 sayıl1 Yüksek Öğretim Kanunu'nun 3. maddesinin (u) bendinde eğitim türlerine göre şu şekilde sınıflandırılmıştır. a) Örgün Öğretim, b)Açık Öğretim, c) Dışarıdan Öğretim Ve d) Yaygın Eğitim( YÖK, Madde 3U). Kanun maddesinin bendinde de açıç̧a görüldüğü gibi eğitim sınıflaması biçimsel ve içeriksel olarak çelişkili olup, gerçeğe dayalı işlevsel bir sınıflama değildir. Eğitim öğretimden daha kapsamlı olmasına karşın, eğitim türleri öğretim ve eğitim olarak sınıflanması biçimsel çelişkiyi ifade etmektedir. Eğitimle öğretimin birbirine eş anlamlı olmayıp, eğitimin daha kapsayıcı olması ise içeriksel tutarsızlı̆̆ı göstermesi göstermektedir. Bunun yanında bu sınıflama yasal eğitim sınıflaması olduğundan abiçimsel (Informal) eğitimi eğitim türleri dışında bırakmasına karşın, abiçimsel eğitimsel bir olgudur. 1) Örgün Eğitim: Öğrencilerin, eğitim ${ }^{3}$ süresince ders ve uygulamalara devam etme zorunluluğunda oldukları bir eğitim türüdür. 2) Açık Eğitim: Öğrencilere radyo, televizyon ve eğitim araçları vasıtasıyla yapılan bir eğitim

\footnotetext{
${ }^{2}$ SWOT analizi, ilk olarak 1960'lı yıllarda Harvard Üniversitesi profesörleri Edmund P. Learned, C. Roland Christensen, Kenneth Andrews ve William D. tarafından geliştirilmiştir(https://tr.wikipedia.org). ${ }^{3}$ Yasa metninde geçen "eğitim ve öğretim" yerine sadece eğitim kullanılmıştır. Bunun nedeni eğitimin aynı zamanda öğrenimi ve öğretimi de kapsamasıdır. Buna karşı öğrenim eğitimi kapsamayabilir.
} 
türüdür. 3) Dışarıdan Eğitim: Yükseköğretimin belirli dallarında, devam zorunluluğu olmaksızın sadece yarıyıl içi ve sonu sınavlarına katılma zorunluluğu bulunan bir eğitim türüdür. Bu eğitimi izleyen öğrenciler ortak zorunlu dersler ile gerekli görülen bazı dersleri, ilgili yükseköğretim kurumlarınca mesai saatleri dışındaki uygun saatlerde düzenlenecek derslerde alırlar. 4) Yaygın Eğitim: Toplumun her kesimine ve değişik alanlarda bilgi ve beceri kazandırma amacı güden bir eğitim türüdür( YÖK, Madde 3U).

Eğitimin türlerine göre sınıflamasıyla işlevine göre sınıflaması arasında önemli farklılıklar bulunmakta olup, türlerine göre eğitimde abiçimsel (Informal) eğitimi içermemesi yanında örgün eğitimle uzaktan eğitimi birbirinden farklı eğitim biçimi değerlendirilmesidir. Oysa işlevine göre eğitimde biçimsel eğitimde ve uzaktan eğitimde her ikisinde de belli bir plana göre eğitim sonucunda diploma verdiğinden biçimsel (formal) eğitim kabul etmektedir. Ancak bu biçimsel eğitimde eğitim yöntemlerini yüzyüze ve uzaktan (dışardan) eğitim yöntemlerine göre bölümlemektedir. Diğer bir ifadeyle işlevsel olarak uzaktan eğitim ayrı bir eğitim türü olmayıp, bir eğitim yöntemidir. Bu eğitim türlerinden biçimsel eğitim süreci sonunda diploma verilirken, serbiçimsel eğitimde katılım sertifikası verilmektedir. Abiçimsel eğitimin herhangi bir yeterlilik diploması ve sertifikası bulunmamaktadır. Biçimsel eğitim yüzyüze eğitim, uzaktan eğitim ve karma eğitim olarak alt bölümlere ayrılmaktadır. Bunlardan karma (Blended) eğitim hem uzaktan hem de yüzyüze eğitimin birlikte yürütülmesini ifade etmektedir. Diğer bir eğitim çeşidi olan serbest biçimsel (serbiçimsel) eğitim ise biçimsel eğitimin dışında kurslarda, dershanelerde, meslek içi veya hizmet içi kurslarda serbest biçimde bir merakın veya eksikliğin karşılanmasına yönelik eğitsel faaliyetlerdir. abiçimsel eğitim ise ailede, sokakta, pazarda, arkadaşlar arasında, sosyal medyada genellikle bilinçsiz ve bilgiye dayanmayan daha eğitim biçimidir(www.passionineducation.com). 


\section{Şekil 1: İşlevsel Eğitim Biçimleri Ve İçerikleri}

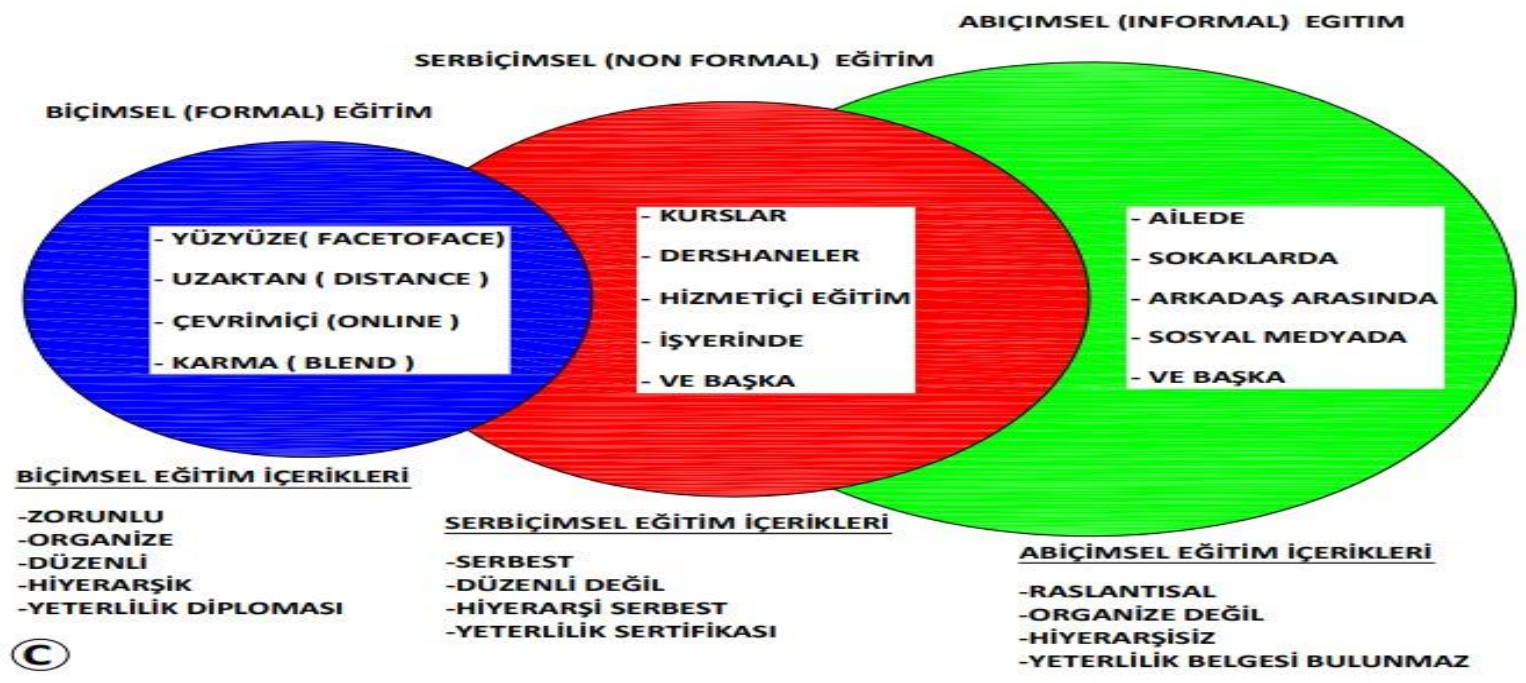

Uzaktan eğitim, derstar ile öğrenci arasında çevrimiçi olarak teknolojik araçlarla bilişsel bilgi alış verişidir. Bu nedenle uzaktan eğitimin bir yanında derstar, diğer yanında ayrı yerlerde olmasına karşın aynı zamanda hatta farklı ülkelerde farklı zamanda yürütülmektedir. Uzaktan eğitimin tarihsel geçmişine ilişkin en eski kaynak 1728 yılında mektupla stenografi dersleri verilmesi gösterilmektedir. Mektupla başlayan eğitimi 1930’lu yıllarda ABD’nde uzaktan radyonun kullanılması izlemiştir. Türkiye'de ise ilk defa mektupla eğitim meslek okulu mezunlarına üniversite eğitimi vermek amacıyla 1960 yılında uygulanmıştır. Bunu 1983 yılında 2547 sayılı Yüksek Öğretim Yasası'nın yürürlüğe girmesiyle Anadolu Üniversitesi bünyesinde Açık Öğretim Fakültesi açılması izlemiştir. Mektupla eğitimi 1980 ve 1990'lı yıllarda Milli Eğitim Bakanlığı'na bağlı Okul Radyosu ve TV Okulu izlemiştir (Uçma, Beycan, 2009:41,42).

\subsection{Kurumsal Çevrimiçi Altyapı}

Kurumsal çevrimiçi altyapı, eğitimde kullanılan fiziksel altyapının bir benzerinin çevrimiçi sistemde kullanılmasını ifade etmektedir. Ancak günümüzde henüz bu fiziksel yapıların bir benzerini çevrimiçi olarak kullanabilecek bir kurum yeryüzünde henüz mevcut değildir. Kurumsal çevrimiçi altyapının etkin olabilmesi yüz yüze eğitimdeki gibi karşılıklı interaktif iletişimin sağlanacağı sanal sınıflar yanında, öğrenci ve dersi yürüten derstara destek hizmeti veren personel ile iletişimi de gerektirmektedir. Bunun yanında kurumsal kimliğin öğrenci ve çalışanlarından 
oluşan kurumdaşların ${ }^{4}$ çevrimiçi sisteme kolay erişebilir olmasını gerektirmektedir. Bu amaçla kurumsal kimliğin parçası olan kurumdaşların bireysel teknolojik olanaklara sahip olup olmadıklarının belirlenmesini gerektirmektedir. Çevrimiçi derslerde derslere katılımda bu teknolojik olanaklara ve bölgesel altyapıya sahip olmayan öğrencilerin derse katılamaması uzaktan eğitim kalitesini düşürecektir.

Sermeçeli, Kurnaz (2020) muhasebe öğrencilerinin pandemi dönemindeki çevrimiçi eğitimleri konusunda yaptıkları çalışmasında, yüzyüze eğitimin uzaktan eğitime göre daha iyi olduğunu belirtmiştir. Buna karşın uzaktan eğitimin yüzyüze eğitime nazaran daha esnek olduğunda, video kayıtlarının tekrar izlenebilirliği olduğunu ve sağlı (hangi sağlık?) açısından olumlu bulduklarını belirtmişlerdir. Covid-19 döneminde psikolojik olarak öğrencilerin kendilerini iyi hissetmediklerinden ödev, sınavlara odaklanma sorunu yaşadıklarını belirtmişlerdir. Uzaktan eğitimde en yaygın sorun internete ulaşım sorunu olarak ortaya çıkmıştır. Öğrencilerin bu nedenle uzaktan eğitim sistemine bakış açılarının olumsuz olduğu görülmüştür (Sermeçeli, Kurnaz, 2020:51-52). Akgün (2020) Muhasebe öğrencileri üzerine ilişkin yaptığı araştırmasında, Covid 19 sürecinde uzaktan eğitimde öğrenciler ile derstarlar arasında etkileşimi olumsuz etkilenmekle birlikte yüzyüze eğitim bir seçenek sunduğunu belirtmiştir. Bunun yanında öğrencilerin çoğunluğu, uzaktan muhasebe eğitimi öğrenciye fotokopi, ulaşım ve taşıma masrafinda avantaj sağlayarak doğanın korunmasına fayda sağladığını belirtmişlerdir. Bu avantaja karşın kız öğrencilerin çoğunluğu, internet kesilmesi, internet hızı sorunu, ders videosunun donması gibi nedenlerin derse odaklanmayı azalttığını belirtmiş̧lerdir. Aynı konuya erkek öğrenciler yüzyüze eğitimin konu anlatılarak veya tahtada gösterilerek öğrencilere sunduğundan daha faydalı olduğunu, buna karşın uzaktan eğitimde bunların etkili olmamasından dolayı beceri ve tutuma yönelik davranışların gerçekleşememesinin olumsuzluk olarak değerlendirilmişsir(Akgün, 2020:231).

Karyağdı (2020), pandemi döneminde muhasebe öğrencileri üzerinde yaptığı çalışmasında muhasebe derslerinin hem teori hem de uygulama gerektiren dersler olduğundan yüzyüze eğitimin genellikle daha başarılı olduğu tespit edilmiştir. Özellikle sınıf tahtasında soru çözümüyle derslerin daha iyi anlaşıldığını buna karşın uzaktan eğitimin başarısız olduğu çalışmasında tespit etmiştir. Derstarların uzaktan eğitimde muhasebe ve finans derslerindeki gerçek başarının olumsuz olduğu,

\footnotetext{
${ }^{4}$ Bir kurumun çatısı altında Kurumdan hizmet alan öğrenciler, hizmet veren eğitimciler, yöneticiler ve destek hizmeti veren kişiler için kullanılmıştır.
} 
bu nedenle uzaktan yüzyüze eğitim sistemine yeniden geçildiğinde önceki derslerin tekrarlanmasının öğrenci açısından olumlu olacağını savunmuşlardır (Karyağdı, 2020:1272).

COVID19 Pandemi döneminde yapılan araştırmalarda öğrencilerin internetlerinin, bilgisayar, tablet, bilgisayar ve başka teknolojik olanaklarının düşüklüğü ya da farklı bölgesel sorunların oluşması nedeniyle eğitimlerini sürdüremedikleri, dersleri takip etmekte güçlük yaşadıkları tespit edilmiştir. Pandemi sürecinde öğrenciler yaşadıkları en büyük sorunlardan birini olanak kısıtlılığı olarak ifade etmişler ve sisteme girme sorunu yaşamalarından dolayı memnun olmadıklarını belirtmişlerdir. Öğrencilerin aynı fiziksel koşullara sahip olmadığı, bilgisayar ve internet teknolojilerine erişim olanaklarının aynı olmadığı dikkate alındığında uzaktan eğitimde fırsat ve imkân eşitsizliğinin önemli bir sorun olduğu görülmektedir. Öğrencilerin bilgi ve iletişim teknolojilerine erişim olanaklarının eşit olmadığı dikkate alındığında uzaktan eğitim sürecinde öğrenci devam zorunluluğunun göz ardı edilmesinin öğrencilerin firsat eşitsizliğinden dolay1 devamsızlık konusunda mağduriyet yaşamalarının önüne geçeceği düşünülmektedir (Söylemez, 2020:634).

Uzaktan eğitim süresince her kurum, derstar ve öğrencinin aynı teknolojik olanaklara sahip olmadığından gerek teknolojiye ulaşılabilirlikte gerekse yararlanabilirlikte kurumlar ve kişiler arası fırsat eşitsizliği yaratmaktadır. Bu durum eğitim kalitesini engelleyici faktörlerden biri olarak ortaya çıkmaktadır. Bunun yanında uzaktan eğitimde çoğunlukla derslerin sözel anlatımı diğer bir deyişle pasif eğitim yöntemi kullanılması öğrencilerin derse aktif katılımını engellediği gibi, öğretim materyalleri konusunda da zorluklar bulunmaktadır. Öğrencilerin ders esnasında bulundukları ortamın derslik ortamına uygun olmamasından dolayı dikkat dağıtıcı unsurların yoğunluğu yanında internet bağlantı sorunları yanında ses, elektrik ve derse bağlantı sorunları uzaktan eğitimin önemli zorlukları ve acizlikleri olarak ortaya çıkmaktadır(Kavuk, Demirtaş, 2021:69,70). Bunun dişında öğrencinin bulunduğu ortamın derse odaklanmaya uygun olmaması öğrenim kalitesini düşürmektedir.

\subsection{Pandemide Ders Süreci}

Karyağdı (2020) yılında muhasebe ve finans dersi veren akademisyenler ve öğrenciler tarafından pandemiden dolayı çevrimiçi eğitim sistemine adaptasyon, iletişim, öğrencilerin başarısı, öğrencilerin derse katılımları ve başka konuları incelemiştir. Araştırma sonucunda, derstarların 
uzaktan eğitimi genel olarak olumsuz bulduğu yüzyüze eğitimin uzaktan eğitimden daha verimli sonuçlandığı tespiti yapılmıştır. Araştırmasında katılımcılar, uzaktan eğitimin daha az çaba, zaman tasarrufu sağlaması, mekân kısıtlaması olmaksızın öğrenciler her istedikleri ortamdan derse girmesinin yüzyüze eğitim olanakları bulamayan öğrencilere oranla daha kolay erişim sağlamasından dolayı daha yararlı olduğunu belirtmişlerdir. Buna karşın çevrimiçi derslere erişimde; internet, bilgisayar ve başka teknolojik araç ve altyapı yoksunluğundan dolayı bazı öğrencilerin dersleri izleyememesine neden olduğunu belirtmişlerdir. Teknolojin yoksunluklardan dolayı öğrenme sürecinde yaşanan sorunların anında çözülememesi ve sonrasında gelişebilecek olası sorunların da çözümünde iletişim sorunları tespit edilmiştir. Yüzyüze eğitimde soruların eş zamanlı çözülmesinin ders başarısını arttırdığını ancak uzaktan eğitim sisteminin uygulamasının yeterince yapılmadığından buna olanak tanımadığını belirtmektedir. Bunun sonucunda öğrencilerin dersleri kendi becerileriyle başaramadıklarınsan yüzyüze eğitimin uzaktan eğitime göre daha başarılı olduğunu savunmuşlardır (Karyağdı, 2020:1271).

Tuğay, (2021) üniversitelerde uzaktan muhasebe eğitimi alan öğrenciler üzerinde yaptığı çalışmasında öğrencilerin genellikle uzaktan eğitimi benimsedikleri ve yüzyüze eğitim ile eş değer görmelerine karşın, öğrenme ve çevrimiçi sistemin kullanımında sorunlarla karşılaştıklarını tespit etmiştir. Muhasebe derslerinin işlenmesi konusunda öğrenciler, derslerinin uzaktan eğitimle verilmesinden rahatsızlık duymadıklarını üstelik dersleri uzaktan zevkli ve çekici buldukları tespit belirtmişlerdir. Buna karşın derslerle yeterli hazırlıkların yapılmadığını, ders içerikleri ve sürelerinin de yeterli olmadığı belirtmişlerdir. Ayrıca araştırmada muhasebe derslerinin yürütülmesinde uzaktan eğitim sisteminden memnuniyet ile derslerdeki memnuniyet arasında pozitif ve anlamlı ilişkinin olduğu tespit edilmiştir (Tuğay, 2021:393). Görüldüğü gibi Tuğay'ın bulgularına göre öğrenciler çevrimiçi eğitimi engelleyici birçok faktöre karşın, öğrenciler bu eğitim yönteminden memnundurlar.

Pandemi döneminde öğrencilerin genellikle köyde yaşadığı tespit edilmiştir. Öğrenciler genel olarak derslerini akıllı telefonlarından izledikleri belirlenmiştir. Ancak akıllı telefondan derslerini izlenmesi telefon ekranının küçük olması ve internet kotası gibi sorunlar nedeniyle sorunlarla karşılaşıldığı belirlenmiştir. Öğrenciler muhasebe derslerini Covid19 pandemi sonrasında da kampüste geleneksel usullere işlenmesini istemektedirler. Bunun nedenini olarak muhasebe konularının her zaman anlamadıklarından konuları sorabilecekleri bir derstara veya arkadaşa gereksinim duyduklarını belirtmişlerdir. Dersleri okula gitmeksizin uzaktan eğitimle izlemek 
isteyenler, uzaktan eğitimin sağladığı esnek zaman ve mekân olanaklarıyla eğitime olumlu katkı sağladığını belirtmektedirler. Çevrimiçi sistemden 5-25 dakikalık videolar şeklinde izlemek istemektedirler. Bunun yanında uzaktan eğitimde kullanılan çevrimiçi eğitimi ve uygulamalarını pandemi sürecinin başında anlamada zorlanmalarına karşın, sonrasında bu sistemi kolaylıkla kullanabildikleri görülmüştür (Sermeçeli, Kurnaz, 2020:51).

Akgün (2020) Muhasebe dersleri ve öğrencileri üzerine ilişkin yaptığı araştırma sonuçlarına göre öğrenciler muhasebe ve finans derslerinin karşılıklı etkileşim halinde işlenmesi gerekmesi nedeniyle bu derslerin uzaktan katkısı olmayacağı gerekçesiyle olumsuzluk değerlendirilmiştir(Akgün, 2020:231). Derstarların çoğunluğu uzaktan eğitimde verilen ödevlerin öğrencilerin verilen ödevlerin anlaşılmasın zorluğundan dolayı verilen ödevleri de algılamalarının sorunlu olduğunu belirtmişlerdir. Yüzyüze eğitim sisteminde derse katılım disiplinin uzaktan eğitime oranda daha yüksek olduğunu derstarlar tarafından savunmaktadırlar. Muhasebe derslerine katılan öğrenciler genellikle muhasebe ve finans derslerinin anlaşılmasının zor olmasından dolayı etkili bir iletişimi gerekli kıldığını belirtmişlerdir(Karyağdı, 2020:1271).Yapılan çalışmaların bazılarında uzaktan eğitim sürecinin uygulama dersleri için verimli olmadığı, deney yapamamanın eksiklik olduğu belirtilmiştir. Pandemi sürecinde farklı ülkelerde yapılmış bazı çalışmalarda da teorik derslerin uzaktan eğitimle işlenebileceği ancak uygulamalı dersler açısından sorunların olduğu ifade edilmiştir(Söylemez, 2020:636).

\section{3.Çevrimiçi Sınavlar}

Ebaid, (2021) muhasebe öğrencileri, çevrimiçi sınavlarda kopya çekmenin yüz yüze sınavlara göre ne kadar kolay olduğu, muhasebe öğrencileri arasında çevrimiçi sınavlarda kopya çekmenin yaygınlığı COVID 19 salgını ve çevrimiçi sınavlarda muhasebe öğrencileri arasında en yaygın kopya davranışları nelerdir? Bir muhasebe örneğine dağıtılan bir anket anketi kullanarak öğrenciler, çalışmanın bulguları muhasebe öğrencilerinin çevrimiçi sınavların onlara yüz yüze kıyasla daha fazla kopya çekme şansı verdiğini algıladıklarını ortaya koymaktadır. Bulgular ayrıca, çevrimiçi sınavlarda kopya çekmenin, COVID-19 salgını sırasında muhasebe öğrencileri arasında yaygın bir olgu olduğunu gösteriyor. Çalışmada çevrimiçi sınavlarda muhasebe öğrencileri arasında en yaygın kopya davranışlarının: başka bir öğrenciye/öğrenciden soruların yanıtlarını göndermek veya almak için cep telefonu metin mesajlarını kullanma, çevrimiçi bir sınav sırasında 
açık bir kitap, çevrimiçi bir sınav sırasında diğer öğrencilere danışmak şeklinde gerçekleştirdiklerini beyan etmişlerdir. Ayrıca başka bir öğrenciden soru almak için çevrimiçi sınava girişi bir süre geciktirmek ve çevrimiçi bir sınav sırasında kişisel sınıf notları olarak tespit etmiştir (Ebaid, 2021:9). Araştırma sonuçlarına göre; sınavlarda ölçme ve değerlendirmenin etkili olmaması, ödev kontrolü yapamama, ders kazanımlarının tam olarak aktarılamamasına neden olmaktadır(Kavuk, Demirtaş, 2021:70).

Pandemi döneminde uzaktan eğitim sınavları esnasında bilgi kaynaklarının kontrol edilememesi ve öğrencinin bu bilgi kaynaklarla bağlantısının kesilememesi nedeniyle sanal başarı artışı gerçekleşebilir (Williams, Kollar, 2021:6). Pandemi sürecinde Uzaktan eğitimde sınavlar, çoktan seçmeli, klasik, performans ödevi ve başka biçimlerde yapılmakta olup, sınav esnasında gerçekte öğrenci sayısı kadar adeta çevrimiçi salon bulunduğundan bu sınavların objektif ve rasyonel gözetlenebilirliği bulunmamaktadır. Sınavlarda öğrencinin gerçeğe dayalı olarak gözlemlenememesi ve kopya çekimine yardımcı araç gereçlerle ilişiğinin kesilememesi öğrencilerin sadece bildikleri arasından özgürce seçim yapmasını engelleyebilmekte, bu durumlar ise etiksel davranışa aykırılık oluşturmaktadır. Sınavlar esnasında öğrencilerin yardımcı araçlardan kendini soyutlayamama sorunu yapılan sınavları işlevselliğini düşürdüğü gibi, öğrenciyi yoketiksel (unethical) davranışlara yönlendirebilmektedir. Öyle ki sınavların performans ödevi şeklinde verilmesi ve ödevlerin genellikle "Word" formatında yazımı ve bunların kontrol süreçlerinin yapılmaması sadece ödevlerin tamamlanıp teslimiyle gerçeklikte ödev sahibinin ödev yükleyen olarak tespitini sağlamaktadır. Sınavlarda derse tahsis edilen sınav süresi, sınavların veya muhasebe dersinin ölçme değerlendire kapsamının nitelikli ölçümüne olanak sağlamamaktadır.

\section{4.Çevrimiçi Eğitimde İletişim}

Yapılan çalışmalarda uzaktan eğitim sürecinde karş̧1ıklı iletişimin olmamasından dolayı öğrencilerin derstarlarla ve arkadaşlarıyla iletişim kuramadıklarından, çoğu zaman sorularına yanıt olanaklarının olmayışından memnun olmadıklarııı belirtmişlerdir. Pınar Vd., (2020) yaptıkları araştırmada öğrencilerin derslerini okulda daha iyi öğrendiklerini, deney yapabildiklerini, anlayamadıkları konuları derstarlara rahatlıkla sorabildiklerini belirtmişlerdir. Ayrıca okul ortamının sosyalleşmeyi sağladığını derslerin daha eğlenceli işlendiğini, okulda sıcak bir atmosferin ve disiplinli bir ortamın olduğunu belirtmişlerdir. Uzaktan eğitim uygulamalarıyla 
işlenen derslerde teknik sorunların yaşanabilmesi, ders dışında derstara soru sorma konusunda sıkıntıların yaşanabilmesi ve uzaktan eğitimde etkileşimin kısıtlı oluşu gibi faktörler bireylerin eğitim algılarını olumsuz etkilemektedir. Elcil, Şahiner (2014) tarafından yapılan çalışmada da uzaktan eğitim sürecinde derstar -öğrenci etkileşiminin yetersiz olduğu, güdüleme ve derse odaklanamama gibi sorunların yaşandığını ve bu nedenle geleneksel eğitimle işlenen derslerin uzaktan eğitimle işlenen derslere göre daha verimli olduğunu belirtmişlerdir. Güdüleme, uzaktan eğitimde öğrencilerin derse devamının sağlanmasında önemli bir faktördür. Öğrencilerin güdüleme düzeylerinin yoğunluğu çevrimiçi öğrenme süreci içinde önemlilik arz etmekte olup, kalıcı öğrenme çıktılarının edinilmesinde de etkili olmaktadır (Söylemez, 2020:635, 636).

Araştırma sonuçlarına göre; öğrencilerin kendi aralarında ve derstarlarla olan iletişim kopuklukları, dikkat eksiklikleri, içinde bulundukları pandemi koşullarında korku ve endişe yaşadıkları tespit edilmiştir. Pandemi sebebiyle uzun süren sosyal soyutlama evsel sorunlar yaşanmasına sebep olduğu belirtilmiştir. Bunun yanında COVID 19'a yakalanma korkusu, yakınlarını kaybetme korkusu gibi olumsuz duygularla birlikte bazen yakın çevresinde bu hastalığa yakalananlar için taşınan endişeler derstar ve öğrencilerin yaşadığı önemli sıkıntılardan bazılarıdır(Kavuk, Demirtaş, 2021:70). Erkoca (2021) tarafindan yapılan çalışmada ise, uzaktan eğitim sürecinde öğrencilerin derse olan ilgilerinin azlığı karşılaşılan bir sorun olarak ifade edilmiştir (Kavuk, Demirtaş, 2021:70). Öğrencilerin dersle ilgilerinin azlığının önemli bir nedeni de iletişim ve etkileşim olanakları ve ortamının bulunmamasından kaynaklanmasıdır.

\section{Pandemi Döneminde Uzaktan Eğitimin Zoga Analizi}

ZOGA analizi ilk defa 1960-1970 yılları arasında Amerika Birleşik Devletlerinde kullanılmıştır. ZOGA analizi, bir kurumu etkileyen içerdar (internal) ve dişardar (external) gerçekliklerin değerlendirilerek bir durum hakkında genel bir bakış elde etmek için kullanılan ve durumsal ortamda var olan dişardar zorluklar ve olanaklar ile içerdar kolaylıklar ve acizliklerin ortaya çıkarılmasını sağlayan bir yöntemdir. Diğer bir deyişle güç ve acizlikler belli bir dönemde ve durumda mevcut olan unsurlara dayanırken, zorluklar ve olanaklar bir durumun gelecekte ne olacağı ile ilgilidir. Bir durum için kolay yönleri (avantajları), çalışanların beceri ve yeterlilikleri, finansal kaynaklar ve kurumun özellikleri ile ilgilidir. Buna karşın durumun acizlikleri ise durumların dezavantajlarını veya eksikliklerini dikkate alır ve araştırma alanı, zayıf gelişme 
olanakları ile ilgilidir. Ayrıca, zorluklar durumun gelişimi için gereksinim duyulan finansal kaynakların eksikliği ile temsil edilebilir (Daniella, 2017:602).

Bir durumun olanakları çevreyle ve faaliyet gösterdiği koşullarla ilgilidir. Ayrıca olanaklar durumun dış çevresiyle yakından bağlantılı olup, teknolojinin sürekli gelişimiyle olduğu kadar yasal ve başka değişikliklerle de ilgili olabilir. Hem zorluklar hem de olanaklar kontrol edilemez ancak güçlü ve aciz yönler kontrol edilebilir. ZOGA analizinin birçok avantajı bulunmasına karşın, bazı sınırları da vardır. ZOGA analizinin avantajları şunlardır: olanaklardan yararlanmaya, güçlü yönler oluşturmaya, sağlanan bilgiler aracıllğıyla stratejik planlamaya yardımcı olmaya, zararlılıkları ortadan kaldırmaya ve olanakları değerlendirmeye yardımcı olmanın yanı sıra becerileri belirlemeye katkıda bulunurlar. Böylece, bir ZOGA analizi yoluyla bir durumsal veya kurumsal kaynakları ve yetenekleri faaliyet gösterdiği çevre ile ilişkilendirebilir. Sınırlar: ZOGA analizi, kurumsal ortamdaki belirsizliğin derecesi nedeniyle öznel olabilir (Daniella, 2017:602603). Eğitim kurumlarının ZOGA analizi, bu kurumların güçlü ve aciz yönlerini, olanaklarını ve zorluklarını incelemeyi içerir. Bu dört yön belirlendikten sonra, eğitim kurumları, belirlenen sorunları çözmek ve eğitim sistemi stratejisine ulaşmak için güçlü yönler ile olanaklar ve zorluklar arasında ve aynı zamanda zorluklar, olanaklar ve aciz yönler arasında ilgileşim (Korelation) kurmaktadır.

\section{1.Çevrimiçi Eğitimin Zorlukları}

Eğitimde zorluklar bir kurumun veya eğitim bileşeninin başarısını olumsuz yönde etkileyebilecek dış güçlerdir. Rakiplerin rekabet avantajlarından, doğal afetler, eğitim politikaları ve daha fazlası gibi kontrol edilemeyen etkilerden oluşurlar. Zorlukların belirlenmesi, başarının önündeki engellerin ortaya çıkarılmasına yardımcı olması yanında kişilerin başarısı için stratejiler geliştirmesini sağlamaktadır. Eğitimde zorluklar eğitime ulaşmak için gerekli araçlarda yaşanan sorunlar, eğitim alanında gereksinimlerindeki değişiklikler veya eğitimi dışarıdan etkileyebilen ve kontrol edilemeyen olumsuz her şeyi içerir. Zorluklar önceden tahmin etmek ve onların kurbanı olmadan ve gelişimin duraklamadan önce bunlara karşı önlem almak eğitimde belirleyici önem taşır. Bu nedenle dış çevre koşullarındaki zorlukla başa çıkmak için kontrol edilemeyen unsurları bilmek önemlidir. Eğitimde bu zorluklar; 
-Destarlar ve öğrencilerin düşük düzeyli istekliliği öğrenmeyi engelleyici bir faktör olarak ortaya çıktığı gibi, kaynakların verimsiz kullanımıyla eğitim kalitesinin de düşmesine yol açmaktadır.

-Uzaktan eğitimle objektif olmayan ölçme ve değerlendirme sonucunda alınan sanal başarının gerçekte alınan puanların öğrenci becerilerini temsil etmemesi sonucunda ortaya çıkacak olası objektif değerlendirme boşlukları.

- Uzaktan eğitime destek sağlayacak teknolojiye sahip olmayan öğrencilerin veya yeterli internet altyapıya sahip olmayan bölgelerde yaşayan öğrencilerin uzaktan eğitimden yararlanamamaları veya düzensiz yararlanmalarının eğitimde fırsat eşitliğini zayıflatması. Zayıflatılmış firsat eşitliğinin bir nevi telafisi için derse devamsızlıkları gayri resmi olarak dikkate alınmaması beraberinde eğitimde doğrudürüstlüğü zayıflatması.

-Etkin işleyen çevrimiçi kurumsal bir ağa sahip olmamak eğitsel iletişimin öğrenci ve derstar arasındaki iletişim bozukluklarına neden olmaktadır. Bu durum ise eğitimde odaklanmayı ve öğrenmeyi olumsuz etkileyici bir yapıya sahiptir.

-Uzaktan eğitim sürecinde kontrol ortamlarının objektif yapılmamasından dolayı kopyala ve yapıştır kolaylığıyla verilen yanıtlarda ve hazırlanan ödevlerde yoketiksel (unethical) uygulamalar fazla olmakla birlikte yoketiksel hazırlanmış ödevlerin paylaşımına da olanak sağlamaktadır. Uzaktan eğitimin kendi doğasından kaynaklanan nedenlerle sınavların yapıldığı alanların tam objektif kontrolü olanaksız olup, bu durum çevrimiçi yapılan sınavların objektiflik düzeyini de düşürmüştür.

- Özellikle pandemi döneminde sokağa çıkma yasakları ve bu esnada sadece ekran üzerinden derslerin izlenmesi, öğrenciler arası ilişkilerde asosyalliğe neden olduğu gibi, kurumsal çevrimiçi ağlar bu asosyalliğin olumsuz etkilerini yok etmekten uzaktırlar.

-Pandemi döneminde uzaktan eğitim süresince gerek derslerin sürekli ekranlardan takibi gerekse sokağa çıkma kısıtlılığından dolayı öğrencilerin gözlerinde görme zayıflıkları yanında şişmanlık sorunların artırmıştır.

-Kurumsal çevrimiçi bağların altyapısındaki eksikler nedeniyle birçok kurum derslerin sürelerinde de kısıntıya gitmiş olup, derslerin yürütümünde çıkan teknik sorunların iletişiminde ve giderilmesinde de sorunlar deneyimlenmiştir. Bunun yanında öğrencilerin derslere katılımları için 
gerekli elektronik destekler belirlenememiş ve birçok öğrenci derslere katılımda istemelerine rağmen sorunlar yaşamışlardır.

-Yukarıdaki zorluklar nedeniyle özellikle üniversiteye yeni başlayan birinci sınıf öğrencilerinin edindikleri sanal başarı düzeyi, eğitim hiyerarşisinin üst sınıflarında ciddi sorunlar ortaya çıkarabilecektir.

\section{2.Çevrimçi Eğitim Olanakları}

Olanaklar kişilerin kendi kontrolü dışındaki gerçekliklerden kaynaklanır ve gelecekte neler yapılabileceğine ilişkin şans sunarlar. Olanakları tespit edebilmek ve kullanabilmek için kişilerin rekabet etme ve pazardaki gücünü gösterebilme yeteneğinde farklllık yaratabilir. Olanaklar, hedeflere ulaşmak için gereksinim duyulan eğitim sisteminin dış ortamındaki koşullarla ilgilidir. $\mathrm{Bu}$ nedenle çevrimiçi eğitim, eğitimciler için en yüksek kalitede dinamik çevrimiçi altyapı tasarlamaları için yeni bir bakış açısı sunabilmektedir.

-Uzaktan eğitimle gerek ders sürecinde gerekse sınavlarda davranışların kontrolsüzlüğü nedeniyle disiplin sorunu oluşturduğu gibi, sınavlarda kopya girişimlerine eğitim kalitesi açısından risk oluştururken, bazı öğrenciler için sanal başarı için olanak yaratmaktadır. Bu durum ise eğitimin amaçlarından birisi olan nitelikli etiksel ilkelere bağlı öğrenci yetiştirme ilkesine aykırılık oluşturmaktadır. Ayrıca etiksel olmayan yollarla öğrencinin derslerde başarılı olması öğrenmeden başarılı olma riskini de beraberinde getirmektedir.

-Çevrimiçi eğitim, hızla dijitalleşen günümüzde ekonomik ve sosyal ve eğitsel olarak özellikle yetişkin çalışan öğrencilerin yaşam boyu öğrenim gereksinmelerini karşılamaktadır. Bunun yanında derslerin izlenmesinde 7/24 derslerin internet üzerinden izlenmesine olanak sağlaması yanında çalışan yetişkinlerin işyerinden derse bağlanmasını olanak tanımaktadır. Bunların dışında çevrimiçi eğitim fiziksel olarak engelli bireye, fiziksel olarak derse katılmak yerine bilgisayarları aracılığıyla sanal sınıfa katılma konusunda daha fazla özgürlük sağlar.

-Uzaktan eğitimle gerek üniversiteler açısından gerekse öğrenciler açısından eğitim maliyetleri düşmekle birlikte evinde uzaktan eğitim için bilgisayarı olmayanlar için eğitim maliyetlerini artırmaktadır. 
-Çevrimiçi eğitimle coğrafi sınırlar olmadığı için, evrensel bir sınıfta bir herhangi bir ülkeden ve zaman farkı olan herhangi bir ülkeden ve herhangi bir yerden veya uzaklıktan uzaktan eğitim sistemine erişebilir. Ancak bütün öğrenciler için coğrafi ve teknolojik şartların buna elvermemesi ise fırsat eşitliğini bozma riski taşımaktadır.

\section{3.Çevrimiçi Eğitim Gücü}

Bir ZOGA analizinde güçlü yönler, bir kişi, kurum veya durumun rakiplerine göre kendisinin daha iyi yaptığı veya kendisini rakiplerinizden ayıran olumlu özelliklerdir. Güçlü yönler bir kurumun ayrılmaz bir parçası olup, neyi herkesten daha iyi yapıyorsa bu özellikleri bünyesinde barındırır. Başarıyı hangi üstünlükler yönlendiriyor? Bir yöntemin yapamadığını hangi yöntem benzersiz veya daha kaliteli karşılamaktadır? Hangi faktörler, eğitim yöntemleri arasında diğerine göre daha güçlüdür? Eğitim yöntemlerinden birinin diğerine üstünlüğü açık bir avantaj sağlıyorsa bu bir güçtür.

- Video derslere, çalışma materyallerine ve sınıf tartışmalarına sürekli erişim, dersi tekrar etmesi veya devam etmeden önce bazı konuları anladığını yansıtmak için daha fazla zaman ayırması gerekebilecek öğrenciler için çok uygundur. Uzaktan eğitim veya öğrenme, büyük miktarda bilgiye erişim kolaylığı yoluyla bilgi ve niteliklerin etkinliğini arttırır. Ayrıca, bugünün öğrencileri, dünyanın herhangi bir yerinde fiziksel olarak bulunabilecek kaynaklara ve materyallere erişebilir.

- Uzaktan eğitimde çok sayıda binaya ve büyük ölçekli sabit gidere maruz kalmadan ve değişken gidere katlanmadan çevrimiçi eğitim verilirken bu kurumsal eğitim maliyetlerini oldukça azaltmaktadır. Bunun yanında çevrimiçi sınıflarda öğrenci sayısı da yüzyüze eğitime göre sonsuz sayıda ve küresel çapta yapılabilmektedir. Bunun yanında öğrencilerin eğitime ulaşmak için yol parasından ve zamandan tasarruf sağlamasıyla eğitim maliyetlerinin azalmasına yol açmaktadır.

\section{4.Çevrimiçi Eğitim Acizlikleri}

Bir ZOGA analizinde dürüst ve gerçekçi olmak objektif bilginin ortaya çıkarılmasında analizin omurgasını oluşturmaktadır. ZOGA analizinin amacına ulaşabilmesi için gereksinim duyulan tüm bilgilerin ortaya konulmasını gerektirdiğinden içerdar acizliklerle yüzleşmeyi gerektirmektedir. 
Bu amaçla birbirine zıt yöntemlerin veya Rakiplerinizin nasıl ve neden daha iyi durumda olduğunu incelemeye olanak sağlamaktadır.

Pandemi döneminde uzaktan eğitim süresince derslerde; okuma ve dinleme şeklinde eğitim çalışmaları yürütülmüş, gerek gruplar arasında gerekse öğrenci ve derstarlar arasında dorudan iletişim eksikliklerinden dolayı eğitim yöntemlerinden aktif ve pasif eğitimden pasif eğitim şeklinde dönüştürülmüştür. Pasif eğitimde öğrencinin dersi dinleyerek ve bireysel olarak okuma yöntemi olup, etkileşim düzeyi en düşük eğitimdir. Oysa muhasebe eğitimi genellikle aktif öğrenmeyi gerektiren eğitim yöntemini kullanmakta olup, bu yöntemde derstar konunun teorisini verdikten sonra uygulamalı olarak adım adım sorunu görsel biçimde öğrencilerin katılımıyla teorik ve pratik olarak özümü gerçekleştirmektedir. Dolayısıyla pandemi dönemi boyunca muhasebe öğrencileri genellikle aktif öğrenme yönteminden yoksun kalmışlardır.

Öğrenim sosyal bir süreç olup, davranış değişimi öğrencinin öğrenme etkinliğine aktif katılımıyla gerçekleşir. $\mathrm{Bu}$ gerçekliğe karşın pandemi döneminde hemen hiçbir sosyal etkinlik gerçekleşmediğinden bu durum beraberinde asosyal eğitimi getirmiş olup, öğrenciler arasındaki asosyallik aynı zamanda öğrenim hızını düşüren bir faktördür. Bunun nedeni öğrenciler sadece sınıf içinde öğrenim görmeyip aynı zamanda ders aralarında ve sonrasında kendi aralarında ders içerikleriyle ilgili paylaşımlar yapmaktadırlar. Ayrıca farklı kültürlerden gelen öğrenciler kendi aralarında kültürel olarak biçimsel alışverişlerde bulunarak ulusal ve uluslararası anlayışın gelişimine katkı sağlamaktadırlar. Bütün bunlara karşın çevrimiçi eğitim bu olanaklardan yoksundur.

Pandemi döneminde uzaktan eğitim boyunca gerek öğrenciler gerek derstarlar arasında gerekse öğrenciler ile derstarlar arasında iletişim asgari düzeyde olup, etkileşim ise yok denecek kadar düşük düzeyde gerçekleşmiştir. Eğitimde etkileşimin düşük olması edinilen bilgilerin içselleştirilmesini olumsuz etkileyici bir faktör olarak ortaya çıkmaktadır. Uzaktan eğitim sisteminde öğrencilerin derse katılımları çevrimiçi olmalarını ifade etmesine karşın, derste etkileşimi oldukça düşüktür. Bu durum yüz yüze eğitim yönteminde de geçerli olmakla birlikte, yüz yüze eğitim yönteminde genellikle gözlemlenebilir bir durumdur. Ancak çevrimiçi katılım elektronik katılım olduğundan hem gözlemlenebilirliği neredeyse olanaksız, hem de beynen katılım yok denecek kadar düşük düzeydedir. 


\section{Sonuç ve Değerlendirme}

Pandemi döneminde biçimsel eğitim yöntemlerinden yüzyüze muhasebe eğitimiyle uzaktan muhasebe eğitiminin etkinliklerinin karşılaştırılması amacıyla pandemi dönemimde yapılmış nicel ve nitel çalışmaların verileri bu çalışmanın ZOGA analizinde veri olarak kullanılmıştır. Stratejik değerlendirme aracı olarak kullanılan ZOGA analizi, Zorluklar, olanaklar, güç ve acizlik kavramlarının baş harflerinin birleştirilmesiyle oluşturulan bir kavramdır. ZOGA analizi, stratejik yönetim, planlama, denetim, eğitim ve başka alanlarda herhangi bir konuda objektif ve rasyonel durum tespiti ve bunun analizlerinde kullanılan bir durum analiz yöntemidir. ZOGA analizi Türkçe alıntyayında genellikle İngilizce SWOT kavramı olarak kullanılmakta olup, bu kavramın İngilizce açılımı; "Strengths, Weakness, Opportunites, Threats" kavramlarının baş harflerinin birleştirilmesiyle oluşturulmuş bir kavramdır. ZOGA kavramı ve analizi kendi içinde kontrol edilebilen ve edilemeyen faktörler olarak ikiye ayrılmaktadır. Bu analiz veya kavramdaki kontrol edilemeyen faktörler zorluklar ve olanaklardan oluşan "ZO" kontrol edilemeyen dişardar (external) gerçeklikleri göstermektedir. ZOGA Kavramındaki gü̈ç ve acizliklerden oluşan "GA” ise kontrol edilebilen içerdar (internal) faktörleri içermektedir. Diğer bir deyişle ZOGA analizi kontrol edilebilen ve edilemeyen faktörlerin güçlü ve zayıf yanlarının matriks bilgisinden oluşmaktadır.

Şekil 2. Yüzyüze Ve Çevrimiçi Eğitim Yöntemlerinin Karşılaştırmalı ZOGA Analizi

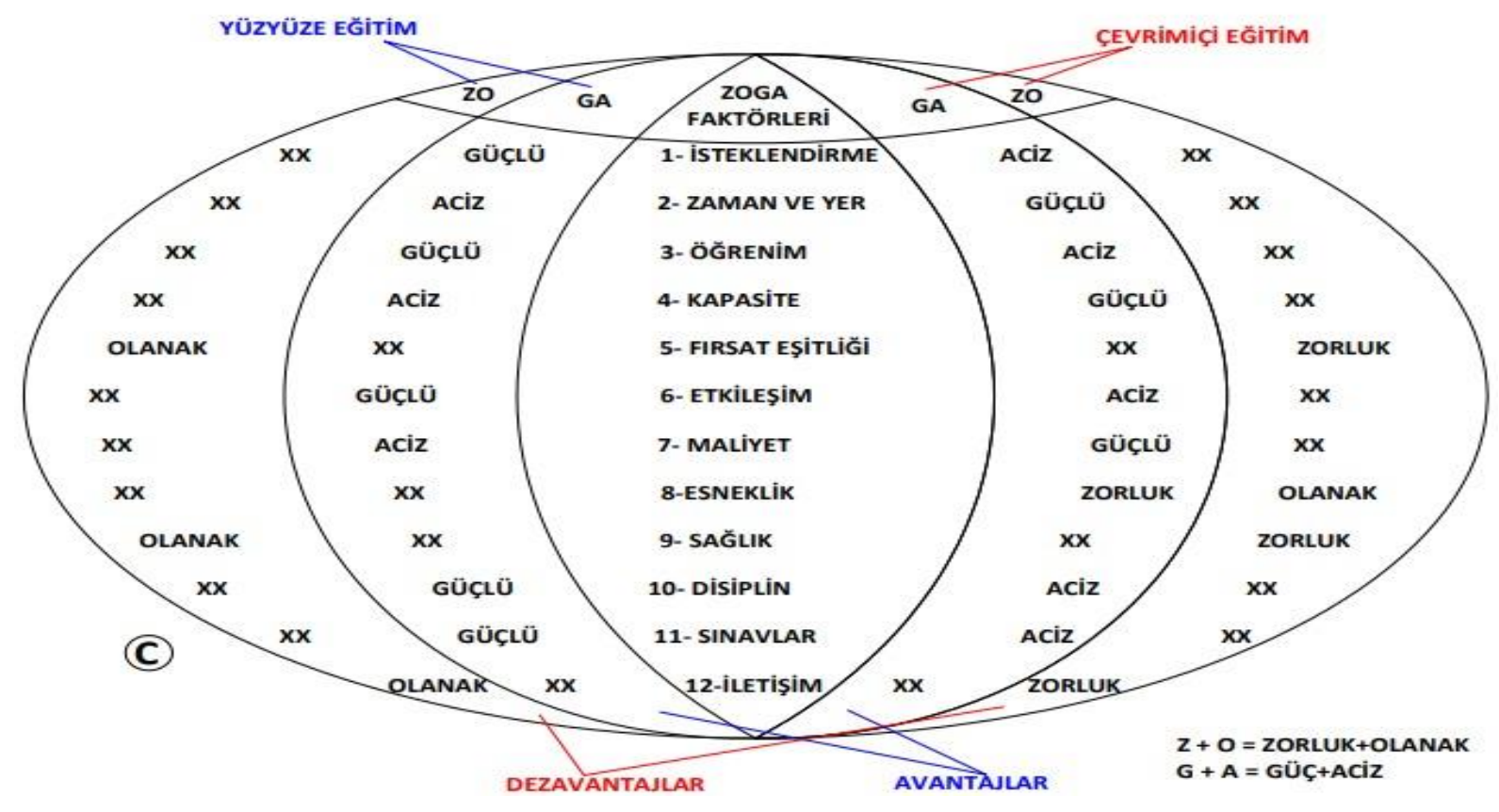


Kaynak, Nina, 2010 ile Uçma, Beycan 2009'dan geliştirilmiştir.

COVID 19 pandemi döneminde üniversitelerdeki muhasebe eğitim üzerine yapılan 7 adet nitel ve nicel çalışmanın incelenmesiyle yüzyüze eğitim çevrimiçi eğitime oranla birçok faktör açısından daha fazla avantaj taşımaktadır. Yukarıdaki Şekil 2'de görüldüğü gibi, yüzyüze ve çevrimiçi eğitimin kontrol edilemeyen zorluk ve olanakların birleşiminden ZO kavramı oluşmaktadır. ZOGA analizinde bir eğitim yönteminin kontrol edilemeyen sağladığı olanaklar diğer eğitim yönteminin zorluklarını ortaya çıkarmaktadır. Buna göre çevrimiçi eğitim kontrol edilemeyen faktörler içinde yüzyüze eğitime göre sadece derslerin serbestçe izlenmesinde bir olanağa sahiptir. Buna karşın çevrimiçi eğitimin yüzyüze eğitime göre zorlukları en başta öğrenciler ve üniversiteler arası firsat eşitsizliği yaratması yanında göz ve şişmanlık gibi sağlık sorunlarına neden olmaktadır. Yüzyüze eğitimin kontrol edilebilen avantajları güç ve acizliklerin birleşiminden GA kavramı oluşmaktadır. ZOGA analizinde bir eğitim yönteminin kontrol edilebilen güçlü yanı diğer eğitim yönteminin aciz yanını ortaya çıkarmaktadır. Buna göre yüzyüze eğitimin çevrimiçi eğitime göre güçlü yanları oldukça fazla olup bunlar; Öğrencinin derse isteklendirilmesinde, öğrenim başarısında, öğrencinin derse katılımında, disiplinde ve sınavlarda objektif ölçüm yapılmasında çevrimiçi eğitime göre yüzyüze eğitimin büyük üstünlüğü bulunmaktadır. Buna karşın çevrimiçi eğitimin yüzyüze eğitime üstünlükleri; ders zamanı ve derse girişlerde, sınıfların kapasitesinin kullanımında ulaşım maliyetlerinin düşmesi ve kurumsal açısından üniversitenin değişken giderlerin asgariye inmesinde yüzyüze eğitime göre daha güçlü yanları bulunmaktadır.

Şekildeki ZOGA analizi göstermektedir ki gelecekteki olası çevrimiçi muhasebe eğitiminde öncelikle odaklanılması gerekli kontrol edilebilen ancak acizlikler; öğrencilerin derse isteklendirmenin artırılması sorunu, öğrenim veya eğitim yöntemlerinin değiştirilmesi gerekliliği, çevrimiçi derste etkileşimin sağlanması sorunu, derslerde ve sınavlarda disiplinin sağlanması sorunlarından oluşmaktadır. Çevrimiçi eğitimde ikinci planda kontrol edilemeyen sorunlardan öncelikle öğrenciler arası ve üniversiteler arası firsat eşitliğini bozucu sorunlara ve iletişim sorununa odaklanılmasını gerektirmektedir. Ayrıca öğrencilerin biyolojik sağlık sorunlarının önlenmesine ilişkin önleyici ve koruyucu tedbirlere odaklanılmasını gerektirmektedir. 


\section{Kaynakça}

Akgün, Ali İhsan, 2020, “ COVID-19 Sürecinde Acil Durum Uzaktan Eğitimi Yoluyla Verilen Muhasebe Eğitimine Yönelik Öğrenci Görüşleri” Açık Öğretim Uygulamaları Ve Araştırmaları Dergisi, AUAD 2020, Cilt 6, Say1 4, ss. 208-236

Daniela Vitan, 2017, “The SWOT Analysis Of Pre-University Education” “Ovidius” University Annals, Economic Sciences Series Volume XVII, Issue 1, pp. 631-635

Ebaid İbrahim el-sayed 2021, "Cheating among Accounting Students in Online Exams during Covid-19 Pandemic: Exploratory Evidence from Saudi Arabia”, Asian Journal of Economics, Finance and Management, 4(1): pp. 9-19, https://www.passionineducation.com/types-of-education-formal-informal-non-formal/, 20.06.2021

Karyağdı Nazan Güngör, 2020, “ Covid-19 Salgın Döneminde Muhasebe Ve Finans Grubu Dersleri Veren Akademisyenlerin Uzaktan Eğitimde Yaşadığı Sorunların İncelenmesi: Beu Örneği”, USBAD Uluslararası Sosyal Bilimler Akademi Dergisi, Sayı 4, Issue 4, ss. 1254-1275

Kavuk Elif Ve Demirtaş Hasan, 2021, “COVID-19 Pandemisi Sürecinde Öğretmenlerin Uzaktan Eğitimde Yaşadığı Zorluklar”, E-Uluslararası Pedandragoji Dergisi (E-UPAD) Cilt: 1, Sayı: 1, Ss.55-73, Nisan , ss.58-73

Nina Bencheva, 2010, "Learning Styles And E-Learning Face-To-Face To The Traditional Learning”, Научни Трудове На Русенския Университет - 2010, Том 49, Серия 3.2, pp 63-67 Serçemeli Murat Ve Kurnaz Ersin, 2020, “COVID-19 Pandemi Döneminde Öğrencilerin Uzaktan Eğitim Ve Uzaktan Muhasebe Eğitimine Yönelik Bakış Açıları Üzerine Bir Araştırma”, Uluslararası Sosyal Bilimler Ve Akademik Araştırmalar Dergisi, C:4/S:1, Y11 4, ss. 40-53

Tuğay Osman, 2021, “ Üniversite Öğrencilerinin Covid-19 Sürecinde Uzaktan Eğitimle Almış Oldukları Muhasebe Dersleri İle İlgili Bakış Açıları Üzerine Bir Araştırma”, Muhasebe Bilim Dünyası Dergisi, Haziran, 23(2), ss.380-396 
Uçma Tuğba Ve Beycan Mehmet, 2009, "Muhasebe Eğitiminde Uzaktan Eğitim Ve E-Öğrenme”, Muhasebe Ve Vergi Uygulamaları Dergisi, 2008/3, ss.35-50

Williams Valerie ve Kollar Robert, 2020, "Impact of COVID-19 in Accounting Education", Journal of Digital Business System and Management, Vol.1, No.1 (2021), pp. 45-50

YÖK Kanunu, 2547 Sayılı Yüksek Öğretim Kanunu, https://www.mevzuat.gov.tr, 25.06.2021 